\title{
The use of literacy approach to teach writing of descriptive text at the seventh grade students of SMPN 1 Ngebel
}

\author{
Tanti Yuliani \\ Department of English Teaching, Universitas PGRI Madiun, Indonesia
}

\begin{tabular}{l} 
Article Info \\
\hline Article history: \\
Received January 18, 2019 \\
Revised March 22, 2019 \\
Accepted June 18, 2019 \\
\hline
\end{tabular}

Keywords:

descriptive text;

literacy approach and teaching; writing.

\begin{abstract}
The main purpose of teaching learning English in Junior High School to develop the students' competence and knowledge in four language skills, Speaking, Reading, Listening and Writing. One of the difficult skills is writing. In this research are describe how are the uses, problems, and solutions of the use of Literacy Approach to Teach Writing of Descriptive Text At The Seventh Grade Students of SMPN 1 Ngebel. Literacy approach is one of the approaches used to teach writing especially in descriptive text because Literacy approach is the ability to read and write. There are some step of teaching writing, they are planning, composing, and revising. This research uses descriptive qualitative research. Participant/Informant of the research are the English teacher and the seventh grade students of SMPN I Ngebel Ponorogo. This research uses purposive sampling technique. The techniques which are used to collect the data are observation, interview, and documentation. Techniques of the data analysis are data reduction, data display and drawing conclusions. The result of the analyzing data indicates that the uses of literacy approach in teaching writing of descriptive text are divided into two steps. The first is preparation steps and the second is learning process. The learning process uses literacy approach includes introduce and giving explanation the descriptive text, give the modal of the descriptive text and have text to analyze, make group work to discussion the students' ideas, give the chance to make students' own product and also checking the students' understanding about the material. Besides, the problem of the use literacy approach in writing of descriptive text are sometimes the students are noisy in the classroom and their vocabulary are still low. The students feel afraid to deliver their opinion and ideas in teaching and learning process. The solution of the use literacy approach in writing of descriptive are the students must make group work of the students' worksheet, Teacher controls the students and gives scores for students.
\end{abstract}

Copyright $@ 2019$ Department of English Teaching. All rights reserved.

\section{Corresponding Author:}

Tanti Yuliani

Department of English Teaching, Faculty of Teacher Training and Education

Universitas PGRI Madiun

Jalan Setiabudi No.85 Madiun

Email: tantiyuliani23@yahoo.com

\section{INTRODUCTION}

English is one of the languages that are widely used in the world. It is an important means of communication in the global community. According to Gerhand in (Nuri, Erlik 2011: 1) "English is studied by people who live in different place where it is not the first language of that people who live in". It means that English is used by people in the world as a second language. English language learners have to master language skills: listening, speaking, reading, and writing. It is supported by Bambang Yudi Cahyono (2010:ix), "When learning a language, people need to possess what native speakers or competent users of language possess, that is skills in listening, speaking, reading, and writing". The four skills have been taught from elementary schools, junior high school, senior high school, until university. Among the four skills, 
writing is the most difficult skills. Luluk Rahmawati in (Bambang Yudi Cahyono, 2010:27) states "Writing is one of four language skills that should be taught to the students".

Writing is one of the English skills. It is supported by Pryla Rochmah Wati in (Bambang Yudi Cahyono, 2009:50) "Writing is one of the four basic language skills which plays an important role in the context of english teaching as a foreign language in Indonesia." Nunan (2003: 88) also states "Writing is the mental work of inventing ideas, thinking about how to express them, and organizing them into statements and paragraphs that will be clear to a reader". Based on theories above, it can be concluded that writing is one of the four basic language skills used to express ideas and feelings and to organize them into statements and paragraphs. Writing is a process that includes many stages. It is important for teachers and students to know the process of constructing text. According to Peters and Smith in (http://www.classroom.pdf.pages:21) "During the Class daily writing block teachers clarify for students the differences between the authorial aspect of writing (planning, composing, revising) and the secretarial aspect of writing (recording and publishing)". It means that writing process consists of planning, composing, and revising.

Based on interview with students of SMP N 1 Ngebel especially the seventh grade students. The researcher found some problems in teaching learning process. The students are also still confused about the grammar, vocabulary, and content of descriptive text. The students cannot develop their idea and confused to related one idea to other ideas. Then, the students are passive and keep silent when students face many difficulties about the material. Based on the problem above, the researcher chooses literacy approach as a solution to teach writing. According to Cooper in (Mmela (2006: 19) "Literacy is the ability to effectively use all the language arts of reading, writing, speaking and listening". It means that literacy is suitable and effectively approaches to use of teaching English. By using literacy approach, the students can know the steps to make a good writing and it is very useful for students to express and develop students' ideas. Then, the students have knowledge about descriptive text, the generic structure and language features of descriptive text itself after the teacher uses the literacy approach to teach.

Based on the problem above, the researcher chooses literacy approach as a solution to teach writing. According to Cooper in (Mmela (2006: 19) "Literacy is the ability to effectively use all the language arts of reading, writing, speaking and listening”. It means that literacy is suitable and effectively approaches to use of teaching English. By using literacy approach, the students can know the steps to make a good writing and it is very useful for students when they want to express and develop students' ideas. Then, the students have knowledge about descriptive text, the generic structure and language features of descriptive text itself after the teacher uses the literacy approach to teach. The teacher more active to create and build the concept of teaching learning process in classroom.

\section{RESEARCH METHOD}

In this research, the researcher uses qualitative method research. The researcher uses qualitative method to study phenomena from the object of the research. It is about the implementation of the literacy approach to teach descriptive text at the seventh grade students of SMPN 1 Ngebel in Schooling years 2013/2014. According to Holloway in Sary Wahyuni (2012:2), "Qualitative research is a form of social inquiry that focuses on the way people interpret and make sense of their experience and the world in which they live". It means that qualitative research is a social research that focuses on interpretation of people and makes meaning of experiences in human live. Descriptive qualitative is used to analyze data as the type of research. It is supported by Kothari (2004:2), "Descriptive research includes surveys and fact-finding enquiries of different kinds. The major purpose of descriptive research is description of the state of affairs as it exists at present". It means that descriptive research is a research for surveys and fact finding. The descriptive research is a research to solve the problem based on the data.

Beside, the other types of research which is categorized in this research is case study. Yin in (Sari Wahyuni, 2012:10) state, "Case study research method as an empirical inquiry that investigates a contemporary phenomenon within its real-life context, when the boundaries between phenomenon and context are not clearly evident, and in which multiple sources of evidence are used". It means that case study

English Teaching Journal, Vol. 7, No. 1, June 2019: 15-19 
research method as an empirical data based on real phenomenon and context of life. Based on all explanation above, it can be concluded that the type of the research in the study are descriptive qualitative research and case study research. In this research, the source of data is the main point as a key step. According to K. Yin (2011:51) "A source of data-in many case a fieldwork setting (where are you going to get the data that are to be collected?)" it means that source of the data is all informants who give the information in this research. In this research, the data sources are social situation, participant/informant, and document.

The technique of collecting data is conducted to get information which is needed to support the goals of research. According to Yin (2011:130), "The potential data collection activities are: Observing, Interviewing, Collecting and examining, and Feeling”. In the research the researcher only takes 3 data collection. They are: observing, interviewing, and collecting. Based on the types of treating to validity above, the researcher takes triangulation as the data validity. Triangulation is conducted in order to obtain the reliability and the credibility of research findings as well as to increase the research's understanding. The researcher gets the data based on source triangulation. There are from documentation, observation and interview. The kinds of documentation are syllabus, lesson plan, and students' work sheet.

\section{RESULTS AND DISCUSSION}

The observation is conducted in 12th May, 2014. In this research, the observation has some goals. It is to observe the uses of literacy approach in teaching writing of descriptive text, the problem and solution when the research is conducted in classroom practice. The researcher gets clarification from the uses of literacy approach in teaching writing of descriptive text. They are follows: Preparing the material, Determines the Instructional Purpose, Preparing the lesson Plan and Syllabus, Teaching and Learning Process (Pre-Activity, Whilst-Activity, and Post-Activity). The Result of Students' Interview in the Seventh Grade Students of SMPN 1 Ngebel in the schooling year of 2013/2014. Based on the result of interview from the students of SMPN $1 \mathrm{Ngebel}$, the researcher can concluded that by using literacy approach for teaching writing to the seventh grade students. There as follows: Most of students have difficult and afraid to share their opinion or ideas because of limitation of vocabulary and grammar. Most of students like to learn writing English especially learn descriptive text because the teacher uses famous people as a media and literacy as approach of teaching. All of students like the learning activity and the teacher's presents. All of students feel that using literacy approach makes their vocabulary and grammar improves. All of students know the good steps of writing, especially writing the descriptive text. The Result of Teachers' Interview in the Seventh Grade Students of SMPN 1 Ngebel in the schooling year of 2013/2014. The researcher gets data as follows: The teacher uses literacy approach in teaching writing of descriptive text. The teacher uses three steps in teaching learning process. They are pre-activities, whilst-activities, and post-activities.

The implementation of literacy approach to teach writing of descriptive text make some students often noisy and the students' knowledge about English is still low, especially vocabulary and meaning in Indonesia language. The use of literacy approach in teaching writing of descriptive text can make students interested in involving the lesson and enthusiastic in learning process. Teacher also uses picture of the famous people and poster as media. It can makes the students understand and active in the process of teaching and learning process. The teacher asks students to do task individually in the beginning. After that, they make group work to discuss with friends. Teacher controls the students when the process teaching and learning process happens, and the teacher gives score for students. The Result of Documentation are as follows: Lesson Plan (RPP), Syllabus, The Student's name list and score, The photograph.

The implementation of literacy approach in writing of descriptive text can be received well by the students. The implementation is same as the procedures of the theory in chapter two and lesson plan (RPP). The students pay attention the lesson. Students analyze the simple paragraph based on the part of descriptive text there are generic structure and language features. After that, the teacher gives explanation about simple kinds of characteristic people. The students pay attention and listen the teacher explanation. Then, the teacher gives worksheet to the students to describe people based on clues on picture. The students must focus and be careful when reading the clues before answering the questions. They do the worksheet discussions with other students if they find difficulties. The students do it, happily and enjoyable. They can be motivated to do 
worksheet but some of students are noisy in the class. After the students have finished doing their work, the teacher collects it. The teacher and students correct the worksheet. The teacher corrects the worksheet together with the students. The students pay attention and answer it.

There are two problems of the implementation of literacy approach to teach writing of descriptive text. It makes the students noisy in the classroom and the students feel afraid to deliver their opinion and idea in teaching and learning process. Then, the implementation of literacy approach to teach writing of descriptive text have some problems. The teacher must have solution to reduce the problems and the students feel happy and interested to follow the learning process. There are some solutions to solve the problems of the implementation of literacy approach to teach writing of descriptive text

\section{CONCLUSION}

The use of literacy approach to teach writing of descriptive text at the seventh grade students of SMPN 1 Ngebel in Schooling years 2013/2014. They are as follows: (a) The planning of literacy approach to teach writing of descriptive text, before doing teaching learning process, the teacher makes the lesson plan (RPP) and syllabus to teach the material. In the implementation of literacy approach to teach writing of descriptive text, the teacher uses three steps: pre-activities, whilst-activities and post-activities. (b) The implementation of literacy approach to teach writing of descriptive text, the teacher starts the teaching learning process by giving greeting to the students, then the teacher shows the picture as media to make the teaching and learning process more be fun and interesting to the students. Then, the teacher gives explanation students can read and write correctly. The last, the teacher gives worksheet and collects the worksheet.

The problems of implementation of literacy approach to teach writing of descriptive text at the seventh grade students of SMPN 1 Ngebel in Schooling years 2013/2014. They are as follows: (a) Sometimes the students are noisy in the classroom and their vocabulary is still low. (b) The students feel afraid to deliver their opinion and idea in teaching and learning process. The solution is done to solve the problems in implementation of literacy approach to teach writing of descriptive text at the seventh grade students of SMPN 1 Ngebel in Schooling years 2013/2014. They are as follows: The teacher asks students to do task individually in the beginning. After that, they make group work to discuss with friends. Teacher controls the students when the process teaching and learning process happens, and the teacher gives score for students.

\section{REFERENCES}

Alawi, Fikri.F. (2011). Improving Students' Ability in Writing Descriptive Text Using Clustering Technique. Tesis tidak diterbitkan. Jakarta: Faculty of Tarbiyah and Teachers Training Syarif Hidayatullah State Islamic University

Bogdan, R. C., and Bikien, S.K. (2007). Qualitative Research for Education an Introduction to Theory and Methods. United State: Pearson Education, Inc.

Brown, H. D. (2000). Principles of Language learning and Teaching: Fourth Edition. San Fransisco: Logman.

Brown, H.D. (2004). Language Assessment Principles and Classroom Practices. San Fracisco: Longman.

Cahyono, B. Y. (2009). Techiques In Teaching EFL Writing. Malang:State Universitas of Malang Press.

Cahyono, B. Y. (2010). The Teaching of English Language Skill and English Language. Malang: State Universitas of Malang Press.

Edge, J. (1991). Essentials of English Languange Teaching. London: Logman

Kern, Richard G. (2000). Literacy and Language Teaching. Oxford: Oxford UP.

Kothari, C.R. (2004). Research Methodology. India: New Age International\

Lodigo, M.G, Et al. (2006). Methods in Educational Research. San Francisco: Jossey Bass.

English Teaching Journal, Vol. 7, No. 1, June 2019: 15 - 19 
Narayana, S. P.V.V \& Krishna, G. (2004). Cirriculum Developement and Management. New Delhi: Discovery Publishing House.

Mmela, E. (2006). Implementing Integrated Literacy Approaches in an English Classroom in Malawi. Tesis tidak diterbitkan. Virginia: Faculty of the Virginia Polytechnic Institute and State University

Atiningsih, N dan Styadi, E.W. (2011). Teaching English as a Foreign Language. Madiun: Istana

Wahyuni, S. (2012). Qualitative Research Method: Theory and Practice. Jakarta Selatan: Salemba Empat

Rugayamanan. 8 Desember 2012 . Definition of Recount, Report, Narrative, Descriptive and Procedure Text, (Online). (http://rugayamanan.wordpress.compress.com/2012/12/08/definition-ofrecount-report-narrative-descriptive-and-procedure-text, accessed on 20 February 2014) 